
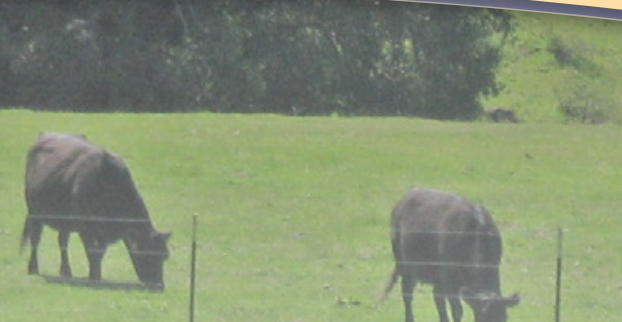

UNDERSTANDING WORKING RANGELANDS

\title{
Caring for Cattle and Sheep to Provide Safe and Wholesome Meat
}

The care and feeding of livestock has a cyclic rhythm tied to the animals' reproductive cycle and seasonal

health needs. Ranchers must perform numerous tasks to keep their animals healthy and reproducing.

Some of these, such as checking and maintaining water sources, are done throughout the year, while others

that require handling the livestock, such as vaccinating and castrating (neutering) male calves and lambs, are done only once or twice each year. Ranchers usually refer to these events as "working" cattle or sheep, and neighboring ranchers often help each other, moving from ranch to ranch.

Range Management Advisor,

Sonoma County; SHEILA BARRY,

University of California Cooperative

Extension County Director and

Livestock Range Management

Advisor, San Francisco Bay Area;

LISA BUSH, Rangeland Consultant;

and and DARREL SWEET, Rancher,

Livermore, California.

\section{Livestock Handing}

When it is time to work livestock, ranchers start by gathering them, known as a roundup. They collect their livestock either on horseback (cattle only), on foot, or by using all-terrain vehicles (ATVs), often accompanied by dogs that help herd the animals into corrals. Corrals include permanent or temporary pens for sorting livestock by age or status (e.g., breed, sex, health), water troughs, and squeeze chutes for holding animals in place while they are being treated (e.g., vaccinated or branded). For efficiency, most routine care practices are done during these roundups. Roundups can be stressful for livestock; as with

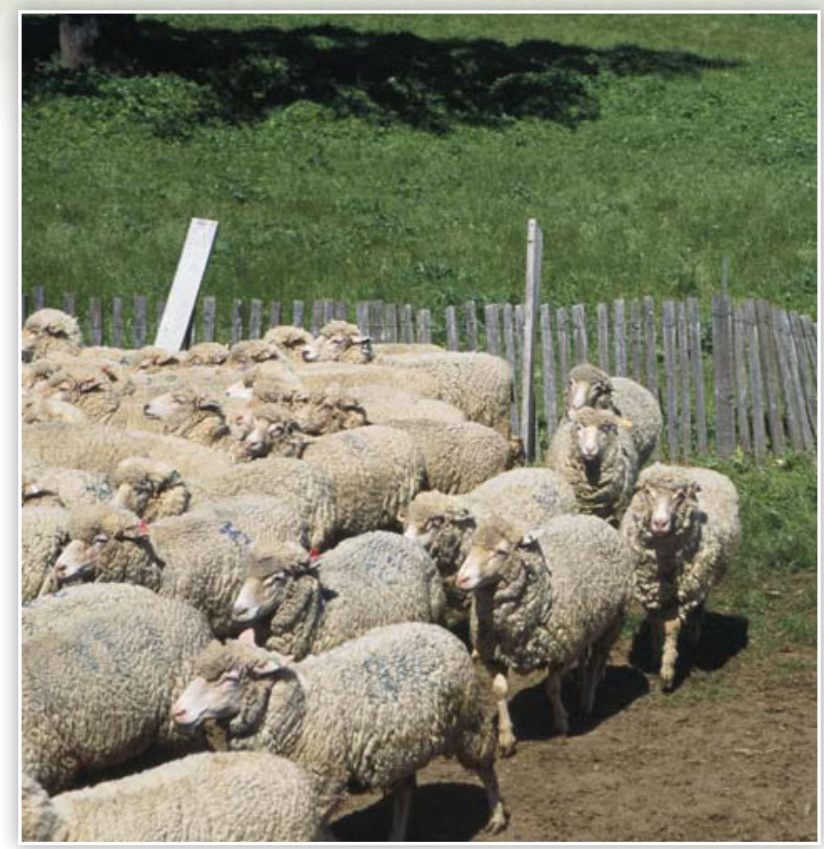

Working rangelands are public or privately owned open space lands that are managed with livestock grazing and rancher stewardship.

Their management contributes to the production of a variety of ecosystem services, including: food, clean water, weed control, wildlife habitat, fire fuel reduction, carbon sequestration, pollination, aesthetic views, cultural heritage, recreational and educational opportunities, and open space conservation. 
humans, stress can decrease disease resistance and cause other health problems in livestock. Livestock handling techniques and facilities, should ideally be designed using low-stress principles (see sidebar) and be well maintained. Ranchers who must work their cattle at sites that do not have proper handling facilities risk injury to themselves and the animals and increase stress on the livestock (see the ANR publication Tools for Healthy Rangelands in the series "Understanding Working Rangelands").

Table 1. Typical animal husbandry activities for a cow-calf operation with fall calving

\begin{tabular}{|l|l|l|l|l|}
\hline Activity & $\begin{array}{c}\text { Year-round, } \\
\text { as needed }\end{array}$ & $\begin{array}{c}\text { Late summer } \\
\text { to early fall }\end{array}$ & $\begin{array}{c}\text { Late fall to } \\
\text { early winter }\end{array}$ & $\begin{array}{c}\text { Spring to } \\
\text { early summer }\end{array}$ \\
\hline calving & & & \\
\hline castrating male calves & & & \\
\hline ear tagging & & & \\
\hline branding & & & \\
\hline dehorning of horned breeds & & & \\
\hline worming/parasite control & & & \\
\hline vaccinations/immunizations & & & \\
\hline breeding (bulls in with cows & & & \\
\hline usually for 90 days) & & & \\
\hline pregnancy checking & & & \\
\hline weaning & & & \\
\hline sorting and shipping & & & \\
\hline hormonal implanting & & & \\
\hline euthanasia/carcass disposal & & & \\
\hline check water supply & & & \\
\hline veterinary care for illnesses & & & \\
\hline salt and mineral & & & \\
\hline
\end{tabular}

\section{Low-Stress Livestock Handling}

Methods used for rounding up, herding, and working livestock can have a major effect on how much stress animals experience during these events. Just as in humans, stress can negatively affect the animals' health and well-being. Stress can reduce milk production, lower disease immunity and weight gain, and cause abortion.

Low-stress livestock handling can also prevent injury to both the livestock and the rancher. Well-designed chutes, corrals, and holding pens use the principles of flight zone behavior (see Larson 2015) and the animals' instincts to help move them, rather than having to force them along while they are worked. Temple Grandin, a well-known animal behaviorist in the Colorado State University Department of Animal Science, pioneered much of the work done on low-stress livestock handling and has designed roughly half of the large-scale livestock handling systems in the U.S. meat industry. Although much of her work focuses on handling animals in large slaughter plants, her website (Grandin.com) includes interesting information on animal behavior and handling principles.

\section{Typical Animal Husbandry Tasks}

A good herd health program is an essential part of a successful livestock business operation and provides safe and wholesome meat. Maintaining herd health includes prevention and treatment of disease and, if disease occurs, preventing its spread. Care by a licensed veterinarian is provided as needed for illnesses or injuries, but ranchers themselves perform virtually all of the herd health and other animal husbandry tasks listed in tables 1 and 2 . These tables show the practices that most ranchers use; although, the practices used and their timing vary by rancher and location.

\section{Calving}

Birthing of calves begins the annual cycle of life on a cattle ranch (see the ANR publication A Year in the Life of a Cow in the series "Understanding Working Rangelands"). In most of California, calving typically takes place in the fall so that growing calves are old enough to use the nutritious and abundant grass and other rangeland vegetation available in spring. Most ranchers will keep cows, especially first-calf heifers (young cows that have not yet calved) that are ready to calve, in a pasture that is easily accessible to the rancher. This enables the rancher to frequently observe pregnant heifers and cows in case one needs assistance in the birthing process as well 
Table 2. Typical animal husbandry activities for sheep with fall to winter lambing

\begin{tabular}{|l|l|l|l|l|}
\hline Activity & $\begin{array}{c}\text { Year-round, } \\
\text { as needed }\end{array}$ & $\begin{array}{c}\text { Fall to } \\
\text { winter }\end{array}$ & Spring & $\begin{array}{c}\text { Early } \\
\text { summer }\end{array}$ \\
\hline lambing & & & \\
\hline castrating male lambs & & & \\
\hline ear tagging & & & \\
\hline tail docking & & & \\
\hline worming/parasite control & & & \\
\hline supplemental feeding & & & \\
\hline shearing & & & \\
\hline hoof trimming & & & \\
\hline breeding (rams in with ewes) & & & \\
\hline sorting and shipping & & \\
\hline euthanasia/carcass disposal & & & \\
\hline check water supply & & \\
\hline veterinary care for illnesses & & \\
\hline salt and mineral supplementation & & \\
\hline
\end{tabular}

as to check and treat newborn calves. Some ranchers may dip the navel of newborn calves with and antiseptic to prevent infection or provide supplemental vitamins and minerals at calving. Castrating, ear tagging, dehorning, and branding are normally done soon after birth. Rather than using a squeeze chute, many ranchers rope calves from horseback and restrain them on the ground for vaccination, castration, ear tagging, and other initial treatments.

\section{Lambing}

In most of California, lambing generally occurs in late fall or early winter, later than calving. It takes less time for a growing lamb to reach market weight than it does a beef calf, so if lambing is properly timed, young lambs can graze and reach market weight on spring grass. Like calving, lambing is scheduled to take advantage of grass and other rangeland vegetation that is most nutritious and abundant in spring. Castrating, tail docking, ear tagging, and vaccinating are normally done soon after birth.

\section{Castration (All Species)}

Castration is typically performed within the first two to three months after calves or lambs are born. The reasons for castrating include

- bulls and rams (intact males) are more aggressive than steers and wethers (castrated males)

- bulls and rams produce meat of a lower quality grade

- bulls and rams could impregnate their mothers and sisters in the herd

Methods of castration include using devices that cut off blood supply to the testicles such as: Burdizzos or emasculators; elastrators (strong rubber bands); or surgical castration (Phillips et al. 2002; Phillips 2006b).

\section{Ear Tagging (Mostly Cattle, Occasionally Sheep)}

Ear tags are attached to livestock for identification. Some ranchers also use insecticide-impregnated ear tags to manage flies that can spread pink eye, a disease that can lead to blindness (Hinkle 2006). Visual identification tags are numbered to identify the animal and sometimes to pair it with its mother. These tags are attached at birth or soon after. Some ranchers also use electronic ear tags that employ radio frequency technology to identify the animal and transmit information about it to a hand-held tag reader. Ear tags are attached with a device that pierces the ear cartilage and inserts the tag, similar to ear-piercing devices used on humans (Phillips et al. 2002; Phillips 2006a).

\section{Branding (Cattle)}

This working time is called "marking." Cattle that are sold or transferred to another owner must be branded according to California state law. Brands are registered with the California Department of Food and Agriculture's Bureau of Livestock Identification. Cattle branding has a long history in California. The first recorded brand (1769) was associated with the Spanish missions. Today there are 22,000 brands in California (CDFA 2010). Brands identify the ranch that the cattle belong to, but they usually do not identify individual animals. Application of a legal brand for ranch identification is most commonly performed using a hot iron (electric or heated in a fire). 


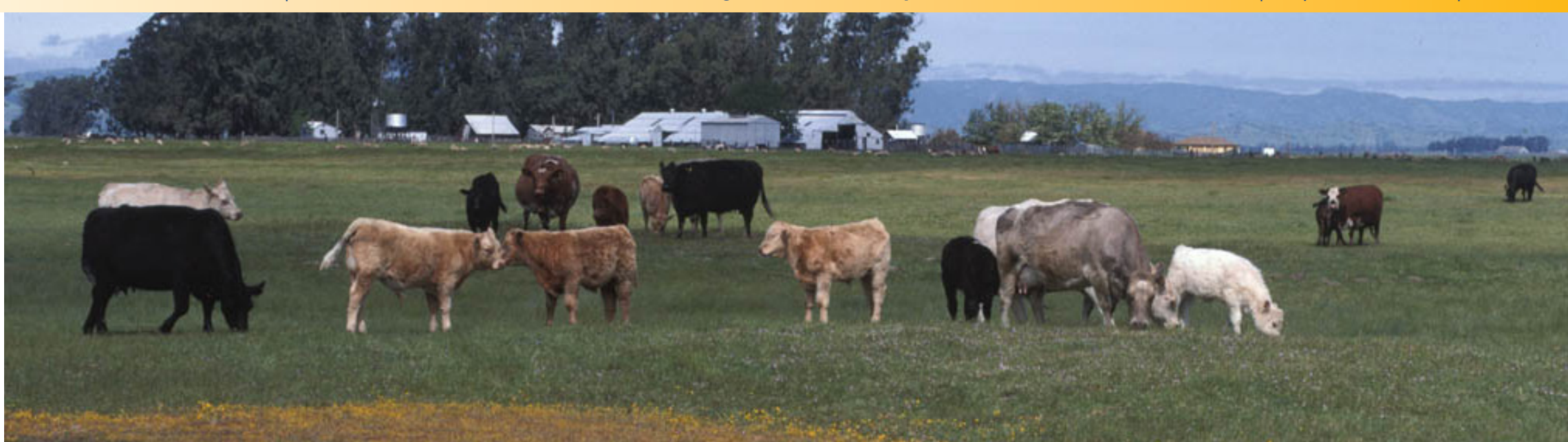

The California Food and Agricultural Code 20003 defines a brand as a design that is permanently impressed on the hide of an animal by burning with acid, a chemical compound, or a hot iron.

\section{Tail Docking (Sheep)}

Tail docking involves shortening a lamb's tail, similar to how some breeds of dogs have their tails shortened. Docking is routinely practiced to keep the rump and remaining tail area free of feces and moisture to prevent blow fly larvae strike or maggot infestations, which can cause open sores and death. Lambs can be docked at 1 or 2 days of age. Methods of tail docking include use of devices such as a Burdizzo, which is clamped on the tail before it is cut off to reduce bleeding; an elastrator, which places strong rubber bands around the tail which causes it to fall off in 2 to 4 weeks; and surgical removal with a hot knife to reduce bleeding (Phillips et al. 2002).

\section{Dehorning (Some Cattle Breeds)}

Although many beef cattle breeds are naturally polled, meaning that they are born without horns, breeds with horns are usually dehorned to prevent injury to other cattle and their handlers. Dehorned cattle also feed better and bring a higher market price (Phillips 2006b). The horn buds can be removed at birth or within the first month. To minimize stress, all calves should be dehorned in an effective, humane manner before 3 months of age (Parsons and Jensen 2012). Methods of dehorning most commonly used include using a hot dehorning iron, a sharp knife, or by applying a caustic paste to the horn buds to prevent their growth (Phillips 2006b).

\section{Worming/Parasite Control (All Species)}

Internal parasite control treatments are available as pour-ons, injectables, oral drenches (oral medication administered into the throat with a syringe) or pastes, boluses (large tablets), or as feed or mineral additives. Dewormers are normally administered to cattle and sheep when parasite loads are the highest, often around calving or lambing (Kvasnicka et al. 2012; Philips et al. 2002). In organic operations, where worming medicines are prohibited, moving animals between pastures may be somewhat effective in breaking the life cycle of some parasites.

\section{Vaccinating (All Species)}

Cattle and sheep are typically vaccinated to protect them from infectious diseases that may cause abortions or other health conditions. Herd health protocols vary within and among ranches, depending on location and prevalence of specific diseases (Mass 2006; Phillips et al. 2002). Some vaccines provide protection for animals while they are living on the ranch. Some vaccines that protect animals during shipping and at the feedlot are required by livestock buyers. These vaccines are typically administered about 1 month before shipping.

\section{Shearing (Sheep)}

Sheep are generally shorn once per year to keep them cooler in hot weather and because the heavy wool provides an ideal environment for blow fly larvae. Just as with tail docking, if this wool is unshorn, blow fly larvae can live and reproduce in it, causing open sores and death. 


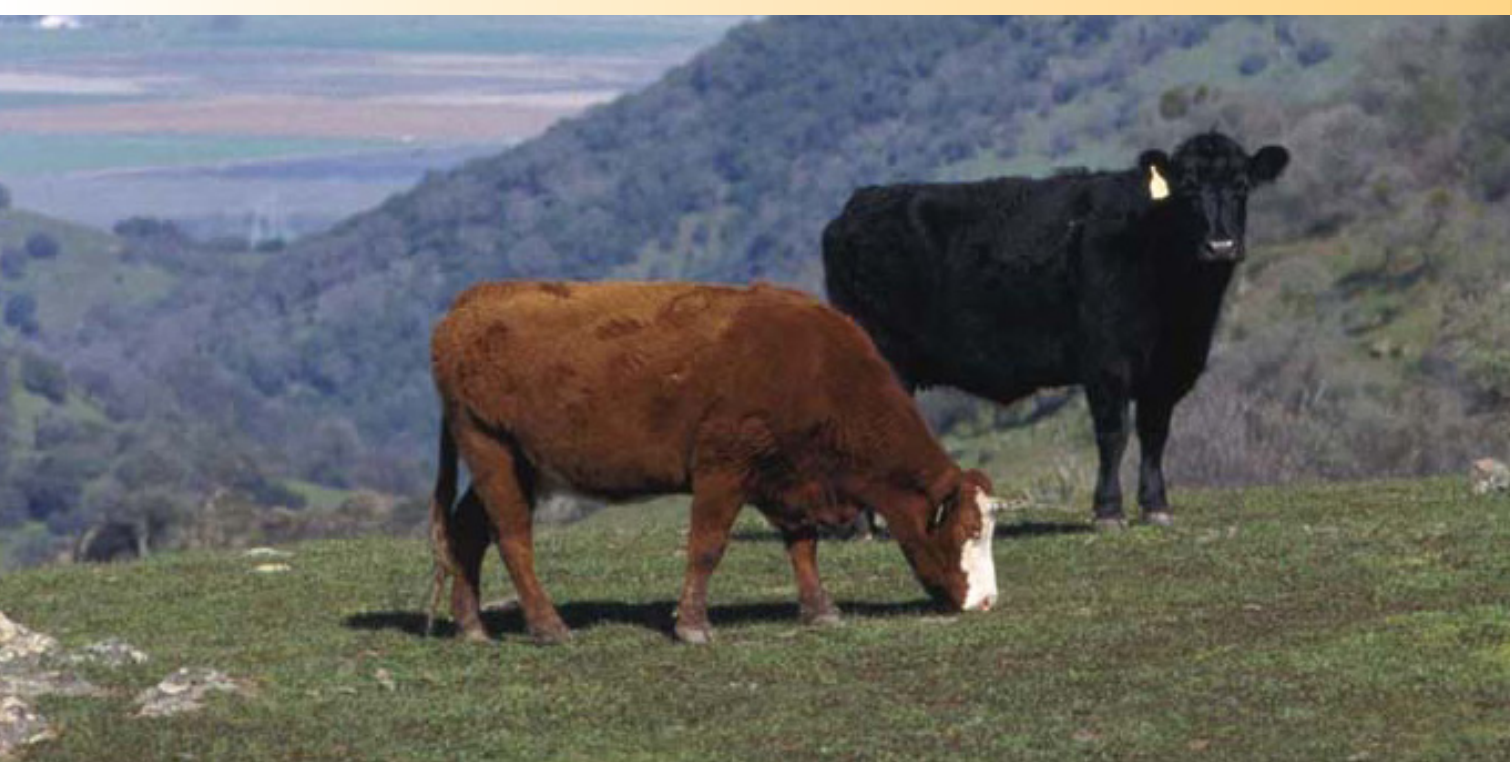

\section{Hoof Trimming (All Species)}

The hooves of sheep grow continuously and are trimmed once a year, usually at shearing time. Overgrown hooves make walking difficult and can cause other health problems. Cattle on rangeland pastures rarely need hoof trimming because walking on the rough terrain keeps their hooves worn down.

\section{Breeding (All Species)}

Sheep, goats, and horses are seasonal breeders, meaning that they can successfully breed only during certain times of year, while cattle can reproduce throughout the year. Most cattle ranchers time their breeding programs so that calves are born in the late summer or fall, except in the mountain areas of California or along the northern coast. Sheep ranchers plan their breeding so that lambs are born in the late fall or early winter. This timing allows the calves and lambs to feed on the nutritious and abundant grass and other rangeland vegetation available in the spring as they grow and start to graze. The breeding season is limited so that calves and lambs will all be born within a short period, ensuring that they will be of similar size when they go to market.

Some breeds of sheep will breed only when day lengths are growing shorter after the summer solstice. Others will breed in the late spring or early summer and will lamb in the fall. It is common for sheep producers to "flush" ewes (female sheep) prior to breeding by feeding the ewes higher-quality feed for a few weeks before breeding. (Phillips et al. 2002). The higher level of nutrition leading up to breeding increases the likelihood of twin births.

Breeding programs are a very important part of a successful livestock operation, especially for ranchers who keep a "closed herd" in which all animals are bred and born on the ranch, rather than being purchased from outside sources. After a few generations the genes in the herd or flock are dominated by the genes of the bulls or rams, which have been carefully selected based on their genetic traits. Breeding of beef cattle and ewes occurs naturally when one or more bulls or rams are put in the pastures with fertile females. Bulls are put out 2 to 3 months after calving to ensure that mother cows become pregnant 9 months before calving season. Rams are put in with the ewes in the early summer, approximately 5 months before the lambing season.

\section{Pregnancy Checking (Cattle)}

A good herd reproductive management program is essential for ensuring a healthy calf crop. Pregnancy checking of cattle is usually performed in spring when cattle are gathered for weaning. Rectal palpation is the most common method used for pregnancy checking cows. The cow's reproductive organs lie just beneath the rectum, making it possible to feel the uterus and ovaries through the rectal tissue. The process, which takes only a few minutes while restraining the cow, involves inserting a gloved hand into the cow's rectum. This is usually done by experienced ranchers or their veterinarians and it is not painful for the cow. Depending upon the presence and size of a fetus and other reproductive structures, rectal palpation can reveal whether the cow is open (not pregnant) or pregnant, and if she is pregnant how far along the pregnancy has progressed. Other tools that may be employed for pregnancy checking include ultrasound and laboratory or on-farm tests on blood, milk, or urine samples. Knowing the reproductive status of heifers and cows is key in a rancher's decisions about whether to keep or sell certain animals, where to keep them, and what their nutritional and health needs are. For example, heifers in their first pregnancy are normally kept in a 
controlled area where the rancher can frequently check on their status as their calving date approaches and help with the birth if needed.

Cows and heifers that are open during the breeding cycle or that have prematurely aborted their calf are normally culled from the herd and sold since the money spent on their care and feeding will probably never be recouped.

\section{Pregnancy Checking (Sheep)}

Knowing the reproductive status of ewes is also key in a sheep rancher's decisions about whether to keep or sell certain animals, where to keep them, and their nutritional health needs. Sheep are much smaller than cows, so rectal palpation to determine reproductive status is not possible. Ultrasound is the most common method of checking pregnancy in sheep. The process is similar to what is used for women. The veterinarian or a technician places a wand on the ewe's belly that can detect a fetus or number of fetuses after about 2 months of gestation. Ewes with multiple fetuses have higher nutritional requirements than those with singles. Ewes carrying twins or triplets can be identified by ultrasound and be separated to receive additional feed or better pastures. Twinning in lambs is a desirable trait and ewes will typically have one to three lambs each year.

\section{Weaning (Cattle)}

Ideally, calves are weaned from their mothers before they are shipped and sold. Weaned calves tend to be healthier than those weaned at shipping time. The combined stress of weaning and shipping at the same time can result in calves becoming ill and not growing well once they reach the feedlot. Weaning can be accomplished by separating the cows and calves or by letting it occur naturally. Natural weaning occurs when the cow doesn't allow her calf to nurse, at around 9 to 11 months of age. Fenceline weaning involves putting cows and calves on either side of a common fence with good-quality pasture on each side for at least 1 month. The cow and calf can still smell each other, but the good pasture reduces the calf's desire to nurse (Pirelli and Zollinger 2012). Fenceline weaning is less common on parklands than on private lands because parklands often lack the fenced areas needed to separate calves from their mothers and because park users are uncomfortable listening to the calves bawling for their mothers. Ranchers grazing in parks try to keep their cows and calves together long enough so that some calves are naturally weaned. In dry years when ranchers are forced to sell early, calves are weaned and shipped simultaneously.

\section{Sorting and Shipping (Cattle and Sheep)}

Typically between late May and mid-July, calves born the previous fall are sold to cattle brokers and shipped to feedlots in the San Joaquin Valley or in other states. Cattle are gathered, weighed, and shipped in lots. Some calves may be held back and sold as stockers to ranchers, who will increase their weight on pasture, then sell them to a feedlot.

Some sheep ranchers sell finished lambs, which weigh 125 to 150 pounds, directly off grass in the late spring. Other lambs are weighed and shipped to feedlots or fields with crop residue for feeding or grazing until they reach market weight. Some ranchers move sheep to mountain or high desert ranges in the summer months.

\section{Hormonal Implants (Cattle)}

Hormones such as estrogens or androgens can be administered as implants to help cattle more efficiently gain lean muscle. The implants come in a slow-release pellet that is placed under the skin on the back of the ear. Depending on the product, the implant will release hormones for 100 to 120 days. All cattle naturally produce these hormones, but implants give them a "boost." Young growing steers or heifers have lower levels of naturally occurring hormones than do bulls or older heifers. The result of implanting cattle is the production of a desirable product (lean meat) that takes less feed to produce in a shorter amount of time. Benefits of implants in growing animals include

- increased weight gain by 10 to $20 \%$

- improved feed efficiency by 6 to $8 \%$

- reduced cost of beef production by 5 to $10 \%$ 
Table 3. Estrogenic activity in food

\begin{tabular}{|l|r|}
\hline & $\begin{array}{c}\text { Nanograms of estrogen per } \\
\mathbf{5 0 0} \mathbf{~ g} \text { (approx. 1 lb) of food }\end{array}$ \\
\hline soybean oil & $1,000,000$ \\
\hline eggs & 17,500 \\
\hline cabbage & 12,000 \\
\hline ice cream & 3,000 \\
\hline peas & 2,000 \\
\hline beef from pregnant cow & 700 \\
\hline beef from implanted cattle & 11 \\
\hline beef from non-implanted cattle & 8 \\
\hline
\end{tabular}

Source: Adapted from Preston 1997.

As reported by the U.S. Food and Drug Administration, people are not at risk from eating food from animals implanted with hormones. The amount of additional hormone in meat from implanted animals is very small compared with the amount of natural hormones that are normally found in meat or that are naturally produced in the human body (FDA 2014). The natural human production of estrogens and androgens is several thousand times the content of a generous serving of beef produced from an implanted animal (Hoffman and Eversol 1986). Other common foods that are naturally much higher in estrogen than implanted beef include eggs, milk, soybean, peas, and wheat germ (Preston 1997) (see table 3).

\section{Euthanasia and Carcass Disposal (All Species)}

Animals that become too sick or badly injured to be saved should be humanely euthanized, and the carcass should be disposed of appropriately. Humane euthanasia can be done by a gunshot using an appropriate firearm and ammunition to the brain, penetrating captive bolt to the brain followed by a secondary method to ensure death, or intravenous (IV) lethal dose of barbiturates administered by a veterinarian (AVMA 2013). Ideally, carcasses should be transported to a rendering facility for disposal or buried on site. California Food and Agriculture Code Sections 9141 and
9142 require that livestock that die from a contagious disease be immediately cremated or buried and transported only to the nearest crematory. The California Department of Food and Agriculture does not regulate carcass disposal for animals that have not died from contagious diseases when the carcasses are disposed of on-site. Regulations regarding on-site burial vary by location. The county department of environmental health or any agency tasked with public health or air (in case of incineration) or water pollution could be involved and have specific requirements or limitations regarding carcass disposal (Doran 2004).

\section{Water Supply Checks (All Species)}

Providing a steady supply of clean drinking water is an essential part of good animal husbandry. Ranchers regularly check springs and troughs to ensure that they are working properly and providing enough water for the herd.

\section{Veterinary Care (All Species)}

Ranchers provide medical care to their animals under the guidance of a large animal veterinarian. The veterinarian recommends vaccinations and treatments for illnesses such as pink eye, but the ranchers themselves usually treat the animals, except in specific cases that require examination by a veterinarian and/or surgery.

\section{Salt and Mineral Supplementation (All Species)}

Livestock may need mineral supplementation based on soil or forage deficiencies. In Bay Area counties and most of California, selenium and copper are typically deficient in livestock and require supplementation. Three methods of selenium and copper supplementation are available for cattle: injections, salt mixes, and slow-release boluses. Sheep may also require supplements, which are usually provided in trace mineral salt blocks or mixes. However, extreme caution is necessary when providing supplements containing copper to cattle and sheep that are grazing together: the level of copper contained in supplements intended for cattle can be toxic to sheep. Like cattle, sheep need copper, but the sheep's copper requirement is much lower, and sheep are very susceptible to copper toxicity (Phillips et al. 2002). 


\section{Supplemental Feeding (All Species)}

Many cattle ranchers supplement pasture forage with hay from summer through winter when pregnant and lactating mother cows have high nutritional needs but forage is low quality. Good nutrition is also important during the breeding season to ensure that cows conceive. Sheep ranchers who supplement their herd's natural forage usually do so in early spring.

Hay can be fed from racks, which reduces the animal's chances of picking up parasites, or from feed spread on the ground. Feeding sites must be accessible throughout the winter by truck or ATV. Urea, a protein supplement to which molasses is added to encourage its consumption, is often provided in plastic or metal tubs.

\section{Proper Care Means a Smaller Impact on the Environment}

Taking proper care of livestock supports the production of safe and wholesome food and makes economic sense for ranchers, but it also reduces livestock's environmental footprint. Advances in animal agriculture, including better nutrition, less stress and mortality, improved health, and technology such as hormonal implants mean that fewer animals produce the same amount of food. Fewer animals have a smaller environmental footprint (Capper 2011) (Figure 1).

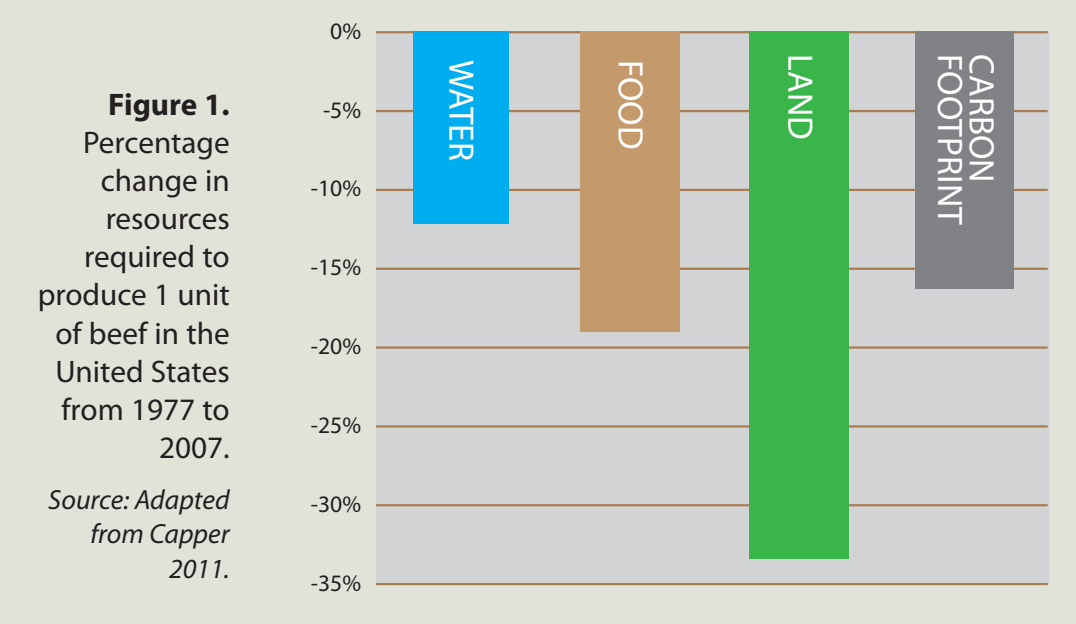

\section{References}

AVMA (American Veterinary Medical Association). 2013. AVMA guidelines for the euthanasia of animals. AVMA website, www.avma.org/KB/Policies/Documen ts/euthanasia.pdf.

Capper, J. L. 2011. The environmental impact of beef production in the United States: 1977 compared with 2007. Journal of Animal Science 89(12): 4249.

CDFA (California Department of Food and Agriculture). 2010. California brand book 2010. Sacramento: CDFA.

Doran, M. 2004 Livestock carcass disposal. Woodland: University of California Cooperative Extension Yolo County. UCCE Solano County website, cesolano.ucdavis.edu/files/59787.pdf.

FDA (U.S. Food and Drug Administration). 2014. Steroid hormone implants used for growth in food-producing animals. FDA website,

Hinkle, N. 2006. External parasites. In D. Drake and R. Phillips, eds., Fundamentals of beef management. Oakland: University of California Division of Agriculture and Natural Resources Publication 3495. 49-56.

Hoffman, B., and P. Eversol. 1986. Anabolic agents with sex hormone-like activities: Problems of residues. In A. G. Rico, ed., Drug residues in animals. Orlando: Academic Press. 111-146.

Kvasnicka, B., R. Torell, and B. Bruce. 2012. Internal parasites of cattle. In Western Beef Resource Committee, ed., Cattle producer's handbook. 3rd ed. Moscow: University of Idaho.

Larson, S., L. Bush, and S. Barry. 2015. Sharing pen space: What to expect from grazing livestock. Oakland: University of California Division of Agriculture and Natural Resources Publication 8516. UC ANR website, anrcatalog.ucdavis.edu/ pdf/8516.pdf.

Maas, J. 2006. Animal health. In D. Drake and R. Phillips, eds., Fundamentals of beef management. Oakland: University of California Division of Agriculture and Natural Resources Publication 3495. 39-45. 
Parsons, C., and S. Jensen. 2012. Dehorning cattle. In Western Beef Resource Committee, ed., Cattle producer's handbook. 3rd ed. Moscow: University of Idaho.

Phillips, R. 2006a. Cattle identification. In D. Drake and R. Phillips, eds., Fundamentals of beef management. Oakland: University of California Division of Agriculture and Natural Resources Publication 3495. 35-38.

Phillips, R. 2006b. Dehorning and castration. In D. Drake and R. Phillips, eds., Fundamentals of beef management. Oakland: University of California Division of Agriculture and Natural Resources Publication 3495. 29-34.
Phillips, R., J. Glenn, M. Dally, M. Filkins, D. Van Liew, and B. Lane. 2002. A handbook for raising small numbers of sheep. Oakland: University of California Division of Agriculture and Natural Resources Publication 21389.

Pirelli, G., and W. Zollinger. 2012. Weaning management for calves. In Western Beef Resource Committee, ed., Cattle producer's handbook. 3rd ed. Moscow: University of Idaho.

Preston, R. 1997. Rationale for the safety of implants. In Symposium: Impact of implants on performance and carcass value of beef cattle. Stillwater: Oklahoma Agricultural Experiment Station Publication P-957. www.fda.gov/AnimalVeterinary/SafetyHealth/ ProductSafetyInformation/ucm055436.htm.

To order or obtain ANR publications and other products, visit the ANR Communication Services online catalog at anrcatalog.ucanr.edu/ or phone 1-800-994-8849.

You can also place orders by mail or FAX, or request a printed catalog of our products from

University of California

Agriculture and Natural Resources

Communication Services

1301 S. 46th Street

Building 478 - MC 3580

Richmond, CA 94804-4600

Telephone 1-800-994-8849

510-665-2195

FAX 510-665-3427

E-mail: anrcatalog@ucanr.edu

(2015 The Regents of the University of California. This work is licensed under the Creative Commons Attribution-NonCommercial-NoDerivatives 4.0 International License. To view a copy of this license, visit creativecommons.org/licenses/by-nc-nd/4.0/ or send a letter to Creative Commons, PO Box 1866, Mountain View, CA 94042, USA.

\section{Publication 8530}

ISBN-13: 978-1-60107-926-8

The University of California Division of Agriculture \& Natural Resources (ANR) prohibits discrimination against or harassment of any person participating in any of ANR's programs or activities on the basis of race, color, national origin, religion, sex, gender identity, pregnancy (which includes pregnancy, childbirth, and medical conditions related to pregnancy or childbirth), physical or mental disability, medical condition (cancer-related or genetic characteristics), genetic information (including family medical history), ancestry, marital status, age, sexual orientation, citizenship, or service in the uniformed services (as defined by the Uniformed Services Employment and Reemployment Rights Act of 1994: service in the uniformed services includes membership, application for membership, performance of service, application for service, or obligation for service in the uniformed services) or any person in any of its programs or activities.

University policy also prohibits retaliation against any employee or person participating in any of ANR's programs or activities for bringing a complaint of discrimination or harassment pursuant to this policy. This policy is intended to be consistent with the provisions of applicable State and Federal laws.

Inquiries regarding the University's equal employment opportunity policies may be directed to Linda Marie Manton, Affirmative Action Contact, University of California, Davis, Agriculture and Natural Resources, 2801 Second Street, Davis, CA 95618-7779, 530-7501318. For information about ordering this publication, telephone 1-800-994-8849.

For assistance in downloading this publication, telephone 530-750-1225.

An electronic copy of this publication can be found at the ANR Communication Services catalog website, anrcatalog.ucanr.edu/. UC This publication has been anonymously peer reviewed for technical accuracy PEER by University of California scientists and other qualified professionals. Thi review process was managed by ANR Associate Editor for Agronomy and Range Sciences Rachael Freeman Long. 